\title{
Comparing precaution in the United States and Europe
}

\author{
JONATHAN B. WIENER* \\ Duke Center for Environmental Solutions, Duke University, Durham NC, USA \\ MICHAEL D. ROGERS ${ }^{\dagger}$ \\ The Group of Policy Advisers, European Commission, Brussels
}

\begin{abstract}
The regulation of health and environmental risks has generated transatlantic controversy concerning precaution and the precautionary principle (PP). Conventional wisdom sees the European Union endorsing the PP and proactively regulating uncertain risks, while the United States opposes the PP and waits for evidence of harm before regulating. Without favouring either approach, this paper critically analyses the conventional depiction of transatlantic divergence. First, it reviews several different versions of the $P P$ and their different implications. Second, it broadens the transatlantic comparison of precaution beyond the typical focus on single-risk examples, such as genetically modified foods. Through case studies, including hormones in beef and milk production and mad cow disease in beef and in blood donations, as well as reference to a wider array of risks, the paper demonstrates that relative precaution varies enormously. Sometimes the EU is more precautionary than the US (such as regarding hormones in beef), while sometimes the US is more precautionary than the EU (such as regarding mad cow disease in blood). Thus, neither the EU nor the US can claim to be categorically 'more precautionary' than the other. The real pattern is complex and risk-specific. Third, the paper seeks explanations for this complex pattern in five sets of hypotheses: optimal tailoring on the merits, political systems, risk perceptions, trade protectionism, and legal systems. None of these hypotheses fully explains the observed complex pattern of relative transatlantic precaution. The paper concludes that differences in relative precaution depend more on the context of the particular risk than on broad differences in national regulatory regimes.
\end{abstract}

KEY WORDS: precautionary principle; risk regulation; European Union; United States; BSE; BST; beef; hormones; blood donations; mad cow disease; comparative law; comparative administrative analysis

\section{Introduction}

The United States and the European Union have recently clashed over the regulation of a number of health and environmental risks, from genetically engineered foods to

*E-mail: wiener@law.duke.edu † E-mail: michael.rogers@cec.eu.int. The views expressed are the author’s and do not necessarily represent the official position of the European Commision. 
climate change to beef. Pervading these specific controversies has been a larger debate about the proper stance of government: how should regulators act in the face of uncertainty about risk?

Some advocate a 'precautionary principle' to justify and mobilize anticipatory regulation of uncertain risks (Cameron and Abouchar, 1991). The notion of precautionary regulation is not new; prominent endorsements have appeared in both Europe and the US since at least the 1970s (Boehmer-Christiansen, 1994; EEA, 2001; Ethyl Corp. v. EPA, 1976; TVA v. Hill, 1978). But in recent years the ambition of precaution as an overarching 'principle' to govern all risk regulation has been growing. It is paid homage in several important international agreements (Bodansky, 1991; Hey, 1992). The treaties that constitute the EU expressly provide that EU environmental policy shall be 'based on the precautionary principle' (EU, 1997, article 174 [ex article 130r]). The European Commission has formally articulated and endorsed the precautionary principle (European Commission, 2000), and the European Environment Agency has published a book on the advantages of precaution (EEA, 2001). Proponents have forecast that it 'could become the fundamental principle of environmental protection policy and law' (Cameron and Abouchar, 1991, at 2). Some assert that the precautionary principle may already be so widely adopted that it is ripening into an enforceable norm of 'customary international law' from which no nation can dissent (Sands, 1995; cf. Sand, 2000).

The United States, however, has not officially adopted the precautionary principle as a general basis for all risk regulation. After endorsements of precautionary regulation in cases like Ethyl Corp. v. EPA (1976) and TVA v. Hill (1978), the US Supreme Court held in the Benzene case (Industrial Union Dept., AFL-CIO v. API, 1980) that OSHA cannot regulate on the basis of mere conjecture about uncertain risks; the court ruled that the agency must demonstrate 'significant risk' before regulating. This decision, and a 1983 guidebook from the National Academy of Sciences, spurred widespread adoption of scientific risk assessment as the basis for American risk regulation over the past two decades, while European regulation has remained more qualitative and informal (Jasanoff, 1986; Jasanoff, 1998). The US insisted on qualifying the statement of the precautionary principle in the 1992 Climate Change treaty (Bodansky, 1993 at 503-04), and the US responded to the European Commission's recent endorsement of the precautionary principle with a long list of skeptical questions.

Today, the conventional wisdom is that Europe endorses the precautionary principle and seeks proactively to regulate risks, while the US opposes the precautionary principle and waits more circumspectly for evidence of actual harm before regulating (Daley, 2000a; McNeil, 2000; Richter, 2000; Levy and Newell, 2000; Kempton and Craig, 1993). In 1999 the Trade Commissioner of the European Union, Pascal Lamy, asserted that 'in the US they believe that if no risks have been proven about a product, it should be allowed. In the EU it is believed something should not be authorized if there is a chance of risk' (quoted in Charnovitz, 2000, p. 295, n.181). As early as 1992, a senior environmental official of the European Commission said that the US 'was definitely leading European policy back in the 1970s and early 1980s' but now 'Europe has certainly managed to catch up' and on some issues 'has taken over the role as world leader' (Henningsen, 1992, pp. 25-6). Fifteen years ago, comparisons of US and European regulation found different procedural approaches but similar degrees of regulatory stringency (Brickman et al., 1986; Jasanoff, 1986; Vogel, 1985). Nowadays, leading 
scholars of comparative regulation are describing a 'flip-flop': on this view, the US used to be more precautionary than Europe in the 1970s, but Europe has become more precautionary than the US since the 1990s (Cadot and Vogel, 2001; Lofstedt and Vogel, 2001; Lynch and Vogel, 2000; Vogel, 2001a, 2001b). Vogel writes:

From the 1960s through the mid 1980s, the regulation of health, safety and environmental risks was generally stricter in the United States than Europe. Since the mid 1980s, the obverse has often been the case (Vogel, 2001b, p. 1).

He emphasizes that these trends

have not produced policy convergence. On the contrary, European and American regulatory policies are now as divergent as they were three decades ago. What has changed is the direction of this divergence. In a number of areas, Europe has become more riskaverse, America less so (Vogel, 2001b, p. 31).

Normative evaluations of this situation vary. Some observers see a civilized, careful Europe confronting a risky, reckless and violent America (e.g., Richter, 2000). To this group, the precautionary principle is an antidote to industrialization, globalization, and Americanization. On the other hand, other observers see a statist, technophobic, protectionist Europe trying to rise to challenge a market-based, scientific, entrepreneurial America (e.g., Redwood, 2001). To this group, the precautionary principle is an obstacle to science, trade and progress.

In this paper, neither of these normative views is adopted. Instead, we critique the factual premise on which both these views rest. We find the conventional wisdom that Europe has now surpassed the US as the more precautionary regulator - to be oversimplified and largely incorrect. The reality is much more complex; issue-specific context is crucial. Sometimes Europe does take a more precautionary stance than the US, but sometimes the US is the more precautionary regulator. This complex pattern is occurring today and occurred in the past. One may find a marked difference in relative precaution on particular risks taken one at a time (such as genetic engineering), but a broader analysis of the evidence across the range of health and environmental risks suggests that there has been no general 'flip-flop' of relative precaution between the US and EU. Ultimately, neither Europe nor America can claim to be the more precautionary actor across the board. Thus, the notion of a great transatlantic struggle over risk and precaution is misleading. And, we suggest, a debate over who is (or a race to be) 'more precautionary than thou' is not the best way to improve regulatory policy or transatlantic understanding.

In order to ground the comparisons of relative precaution across countries, section 2 presents a brief clarification of risk, uncertainty, and the precautionary principle. In section 3, we present a range of risk regulation examples to illustrate the complex pattern of variation in relative precaution between the US and Europe. We then focus on the case of beef, including the use of hormones such as bovine somatatropin (BST) and the spread of 'mad cow disease' (BSE), which have recently been the subjects of conflict between the US and the EU. Section 4 examines a set of hypotheses to try to explain the complex observed pattern of relative precaution. Section 5 recommends further comparative analysis of regulation, and a move from simple principles of precaution toward a more considered holistic concept of 'prudent precaution.' 


\section{Risk, uncertainty and precaution}

All activities involve risk, by which we mean the combination of the likelihood (probability) and the harm (adverse outcome, e.g. mortality, morbidity, ecological damage, or impaired quality of life) resulting from exposure to an activity (hazard). The manifestation of such harm may be prompt or latent.

Uncertainty can be distinguished from probability (Knight, 1933). Some risks (both high and low probability) are well documented and understood, while others (both high and low probability) are highly uncertain. For example, death by cellphone radiation and lightning strikes may both be low probability, but the former may be far more uncertain because we are unsure whether cellphones even cause brain tumors. Of course all risks are uncertain to some extent, because we can never know the future with complete certainty. Science is accustomed to this uncertainty. The public may sometimes assume that regulatory action can be based on 'facts' about what is 'good' or 'safe' and 'bad' or 'unsafe,' and may further assume that these facts are more or less certain. Government sometimes gives credence to this myth, hiding behind claims of scientific knowledge to justify policy decisions (Wagner, 1995). Not only is such belief in the certainty of facts underlying regulatory decisions erroneous, but the failure to recognize the underlying uncertainty is also dangerous: it invites demands for simple choices and assured protections that cannot be satisfied (Rogers, 2001). The public's subsequent realization that the facts are disputed and the protections are imperfect can give rise to public cynicism about government.

In the face of uncertainty about a risk, precautionary measures are often taken, such as building bridges to hold excess weight, and setting radiation exposure limits conservatively. Yet it is never known for sure if these precautionary measures are effective (since their success results in the absence of an adverse outcome that might not have occurred anyway), or whether they are directed at the most important risks. Precaution need not mean prohibition: we typically do not forego entire activities (such as eating or transportation) simply because they might be risky; instead we fashion prudent precautions that are proportionate to the expected risk.

In the face of probabilistic, uncertain and latent risks, government has two basic strategies: ex ante precautions, ex post remedies, or both. Ex post remedies include tort law administered by the courts. Ex ante precautions include regulations administered by agencies. Regulations are precautionary measures taken to avoid uncertain future harms.

Precaution can be considered a continuous variable: on the time path over which a risk is forecast to become manifest, a regulation is more precautionary the earlier it takes effect and the more stringently it restricts the suspected source of the risk. The precautionary principle ( $\mathrm{PP})$ denotes part of the ex ante regulatory spectrum. But there is no single accepted version of the PP. One author catalogues 19 different interpretations (Sandin, 1999). Here we distinguish three main versions of the PP:

Version 1: Uncertainty does not justify inaction. In its most basic form, the PP is a principle that permits regulation in the absence of complete evidence about the particular risk scenario. ' $[\mathrm{L}]$ ack of full scientific certainty shall not be used as a reason for postponing measures to prevent environmental degradation' (Bergen Declaration, 1990). But there is never 'full scientific certainty'; decisions must always be made under uncertainty. This version of the PP rebuts the contention 
that uncertainty precludes regulation, but does not answer the real question: what action to take, given inevitable uncertainty.

Version 2: Uncertainty justifies action. This version of the PP is more aggressive.

'When an activity raises threats of harm to human health or the environment, precautionary measures should be taken even if some cause and effect relationships are not fully established' (Wingspread Statement 1998, in Raffensberger and Ticknor, 1999, p. 353). But cause and effect is never 'fully established.' And if it is unclear what causes the harm, it is unclear what 'measures' would prevent it. Again, the real question is what action to take, given the uncertainty.

Version 3: Uncertainty requires shifting the burden and standard of proof. This version of the PP is the most aggressive. It holds that uncertain risk requires forbidding the potentially risky activity until the proponent of the activity demonstrates that it poses no (or acceptable) risk. For example,

the applicant or proponent of an activity or process or chemical needs to demonstrate that the environment and public health will be safe. The proof must shift to the party or entity that will benefit from the activity and that is most likely to have the information (Raffensberger and Ticknor, 1999, pp. 345-6).

This shift in the burden of proof may elicit information from the least-cost provider, but if the standard of proof is too demanding it may amount to overregulation.

\subsection{CONFLICTING ERRORS}

All of these versions of the PP, and indeed all choices between ex ante and ex post legal systems, confront the tradeoff between two kinds of errors: false negatives and false positives. False negatives occur when an initial finding of no (or acceptable) harm later turns out to have been incorrect. False negatives are risked by presuming 'innocent until proven guilty.' Insufficient $e x$ ante regulation can incur the harms of neglecting false negatives: health and environmental damage (p. 1978). By contrast, false positives occur when an initial finding of (unacceptable) harm later turns out to have been incorrect. False positives are risked by presuming 'guilty until proven innocent.' Hence, adopting precautionary regulations can incur the cost of false positives: financial losses, restricted freedoms, and the foregone health and environmental benefits of restricted technologies. Every regulatory choice involves uncertain future risks and hence a tradeoff between the risks of false negatives and false positives.

\subsection{COUNTERVAILING RISKS}

Page (1978) argued that regulation should err on the side of precaution, on the ground that the cost of neglecting false negatives is harm to health and environment while the cost of regulating false positives is just money. (Cf. Geistfeld, 2001.) But this analysis is incomplete, because any precautionary intervention can also yield unintended side effects - adverse effects on health and environment. Risk regulation, like medical care, can both heal and hurt (Wiener, 1998). Reducing a 'target risk' can increase a 'countervailing risk'; examples are ubiquitous (Graham and Wiener, 1995). Like Odysseus navigating between Scylla and Charybdis, the modern regulator must weigh competing 
risks. Meanwhile, reductions in a target risk might also reduce ancillary risks; the goal is to treat the 'whole patient' (Graham and Wiener 1995, pp. 226-71). Hence an uncertain risk does not automatically imply the need for 'action'; the question is what action to take, in a world of multiple uncertain and interconnected risks. Indeed, given countervailing risks, version 3 of the PP could swallow itself: the proponent of a precautionary regulation - which is a human 'activity' - would have to demonstrate that the precautionary regulation itself would be 'safe' before it could be adopted (cf. Cross, 1996). The solution to this paradox is to step out of the single-risk mindset and see the real world of multiple risks, in which the regulator must optimize tradeoffs across interconnected risks.

\subsection{RECONCILING PRECAUTION AND RISK-BASED REGULATION}

The various and ill-defined notions of precaution need to be connected to, and refined in light of, the better-defined concepts in risk analysis and decision science (Stone, 2000; Stewart, 2002). One of the most nuanced and balanced versions of the PP is contained in the Communication issued by the European Commission in February 2000 (European Commission, 2000). The Commission's approach starts from version 1 above (uncertainty does not justify inaction). It then adds numerous qualifications, such as the need for precautionary measures to be proportionate and attempt to maximize net benefits, in light of the costs and risks of the various alternatives (including the alternative of no action); and the need to undertake research to reduce uncertainties even after precautionary measures have been introduced. Despite having several ambiguities and potential shortcomings, the Commission's Communication is in many ways similar to the US guidelines for regulation in Executive Order 12866 (which requires, among other things, that regulations be based on sound science and maximize net benefits) (Clinton, 1993). Given the similarities between these two documents, one might expect some greater convergence between the US and Europe on regulatory policy in the future. In both cases, the documents provide a sensible framework for regulation, but the actual outcomes will depend on how that framework is interpreted and implemented.

\section{Transatlantic Comparisons}

\subsection{BROADENING THE ANALYSIS}

As noted above, the conventional wisdom is that Europe is now more precautionary than the US. This view has become commonplace, and is the premise for critiques flung from both sides of the Atlantic. But this premise rests on selective attention to only a few examples, such as genetically modified organisms (GMOs).

A broader analysis reveals that the reality is a complex pattern of relative precaution, both historically and today. Europe appears to be more precautionary than the US about such risks as GMOs, hormones in beef, toxic substances, phthalates, climate change, guns, and antitrust/competition policy. The US appears to be more precautionary than Europe about such risks as new drug approval, the ban on CFCs in aerosol spray cans and the ban on supersonic transport to protect the stratospheric ozone layer, nuclear energy, lead in gasoline, particulate air pollution, highway safety, teenage drinking, cigarette 
smoking, mad cow disease in blood donations, potentially violent youths, 'right to know' information disclosure requirements, and missile defences. ${ }^{1}$

This broader analysis indicates that neither the US nor the EU is a more precautionary actor across the board, today or in the past. Relative precaution appears to depend more on the particular risk than on the country or the era. This complexity is compounded by the variation within each system: both the US and the EU are federations of subsidiary jurisdictions, with variety in regulatory approaches within each system. Meanwhile, compared to most of the rest of the world, the US and the EU are probably both at the highly precautionary end of the spectrum.

\subsection{BEEFING ABOUT BEEF}

One of the sharpest transatlantic conflicts over relative precaution has been about beef. Here, we explore this example in some detail because it relates so closely to, and yet helps refute, the conventional wisdom of greater European precaution. Recent headlines might suggest that Europe is more precautionary about beef than is the US. But the reality is that Europe has been more precautionary about hormones in beef, while the US has been more precautionary about mad cow disease (BSE) in beef and blood donations. The beef cases are telling because they illustrate the considerable variation in relative transatlantic precaution even within one field of regulation involving the same regulatory agencies.

\subsubsection{Hormones}

a. BST in dairy production. Bovine Somatatropin (BST) is a naturally occurring hormone that controls lactation in cows. It is now commercially produced as an agricultural pharmaceutical, synthesized by bacteria that have had a bovine gene implanted; this form of BST is called rBST. When BST is injected into cows, their milk production can increase substantially. The US FDA approved the use of rBST in November 1993, stating that milk produced from cows that had been given the artificial hormone was indistinguishable from other milk. It is now widely used on US farms. But it is banned in Europe.

The opposition to rBST in Europe was concerned with several impacts: animal welfare (in particular, an increased incidence of mastitis among cows given BST), human health (because farmers may use more antibiotics to counter the mastitis, and these could stay in the milk as well as eventually reduce the effectiveness of antibiotics against bacteria that infect humans), and socioeconomic effects (the potential harm to small farms unable to compete against the economies of scale offered by new technologies). So far, the available scientific evidence does not support the human health fears. Dr. Bangemann (the then EC Commissioner responsible for Industrial Affairs, Information and Telecommunication Technologies) stated:

It is clear that neither from an ethics nor a health viewpoint, is there any argument against BST. The only decision that stands is one based on a political environment with its roots in agricultural beliefs and traditions (Bangemann, 1993).

It must be stressed that although this statement was very robust, the formal European position at that time was that rBST was banned as a precautionary measure by the

1 For a more complete analysis of these examples, see Wiener and Rogers (forthcoming). 
European Council Decision of 25 April 1990 (European Council, 1990). By this Decision, Europe prohibited the administration of rBST in any form to dairy cattle (Article 1) for a period of 10 years (up to 31 December 1999), except for the purposes of carrying out scientific and technical trials (Article 2). There were two main reasons for this prohibition. The first was that the various effects of substances like BST were not sufficiently clear and that a period of time should be provided for in-depth studies; this reason was precautionary in nature. The second reason concerned the internal market and the need to avoid market distortions if different member states took different decisions concerning the use of BST. The EC's Committee of Veterinary Medicinal Products had already found that BST was not a concern to humans. 'Rather, the proposal was based on the fear of Community officials that BST's introduction would undermine the competitive position of small-volume dairy farmers and thus hasten the long-term consolidation of the dairy farm sector' (Vogel, 1995, p. 172; see also Vogel, 1997, pp. 24-5). In addition, the EC had experienced an oversupply of dairy products, which had necessitated government subsidies of dairy farms as dairy prices fell. These subsidies were being slowly decreased in the 1980s. Introduction of BST might have exacerbated the dairy oversupply and thereby required more subsidies in the future (Vogel, 1995). Still, the human health concerns seem to have played some role, if only ancillary; although the PP was not expressly invoked, there were plausible risk scenarios both in terms of animal and human health, but insufficient information, and thus the ban was limited to the time required to obtain further information.

At the end of 1999 the European Council made this prohibition permanent and removed the exception that had been available previously for scientific and technical trials (European Council, 1999). This Decision was based on research that had demonstrated that BST increased the risk of mastitis and increased the duration of necessary treatment for the affliction. Furthermore, there were increases in foot and leg disorders in dairy cattle when BST was administered, together with severe reactions at the BST injection site. Thus for animal welfare reasons, which were required under The European Convention for the Protection of Animals Kept for Farming Purposes, the prohibition was made permanent. Precautionary action under scientific and technical uncertainty (the time-limited prohibition of 1990) had been replaced by a risk management decision based on new knowledge. (The question of possible human health effects was not addressed in these formal decisions.)

By contrast, the US permits the use of rBST. The US FDA began reviewing the use of BST as early as 1989 (US FDA, 1989). The FDA approved the first and only bovine growth hormone used in the US, Monsanto Company's Posilac $\AA$, on 5 November 1993, but controversy regarding rBST safety in the human food supply persists. In April 1998, the Canadian government issued a report that questioned the safety of rBST for humans based on results from a 90-day oral toxicity study conducted on rats which tested the effect of the hormone on antibody responses. This test was conducted for European Union approval of rBST, and the US FDA did not review it during the original approval process for Posilac®. The Canadian study also found significantly higher levels of insulin-like growth factor I (IGF-I) in milk, thus raising concerns for human safety. The FDA then initiated a review of rBST, and in February 1999 issued its report reviewing the current state of the science and concluding that the use of rBST is safe for humans (US FDA, 1999a). 
The European Commission Directorate General XXIV issued a 'Report on Public Health Aspects of the Use of Bovine Somatotropin - 15-16 March 1999' which questioned the safety of IGF-I in milk as a result of the use of rBST (see US FDA, 1999b). The FDA then reviewed the available scientific data on the effect of rBST on IGF-I in the spring of 1999 and reconfirmed that '... the administration of rBST to dairy cows is safe for all consumers, including infants. Additional exposure data are not necessary' (US FDA, 1999b). The FDA also cited two findings of the Joint Food and Agricultural Organization/World Health Organization Expert Committee on Food Additives (JECFA) which found in 1992 and again in 1998 that '. . . [studies have shown that there is] an extremely large margin of safety for humans consuming products from rBST-treated cows' (US FDA, 1999b).

As to rBST, the European approach was more precautionary than the US approach. This finding is consistent with the conventional wisdom that Europe is more precautionary than the US, particularly regarding products of genetic engineering but also about new technological risks in general.

b. Growth hormones in beef production. Other hormones, both natural and synthetic, have been used for some time as growth promoters in beef cattle. The use of such growth promoters has been the subject of a great deal of controversy in Europe and has for some time been totally banned in meat production. Since growth promotors are widely used in the US, Canada, and in several other states, the European ban has given rise to an international trade dispute under the World Trade Organisation (WTO) auspices.

There are six hormones involved in the dispute. Three are naturally occurring: oestradiol-17ß, testosterone and progesterone. Oestradiol-17ß is a sex steroidal hormone with oestrogenic action, i.e. it is responsible for female characteristics, while testosterone is a sex steroidal hormone with androgenic action, i.e. it is responsible for male characteristics. Progesterone is a sex steroidal hormone with gestagenic action, i.e. it is responsible for maintaining pregnancy. All three hormones are produced in animals and humans and are produced throughout life. They are required for normal physiological functioning of the body and for maturation and of course their levels vary with age, sex, tissue and species.

The other three hormones are artificially produced: zeranol (which mimics the action of oestradiol-17ß), trenbolone (which mimics the action of testosterone), and melengestrol acetate (or MGA, which mimics the action of progesterone). In the US, all six hormones are approved for growth promotion purposes. All except MGA are formulated as pellets that are implanted in the ear of the animal; MGA is administered as a feed additive.

These hormones are carcinogenic at high doses in animal experiments, and there are clear indications that these effects occur in humans as well. The essential problem concerns the extrapolation to low doses, particularly because oestradiol, testosterone and progesterone already occur naturally in humans at levels that are arguably greater than those delivered in the meat from treated animals.

European concerns about the use of hormones for growth promotion purposes date from the 1970s. The illegal use of the hormone diethylstilbestrol (DES) in veal production had been implicated as a possible cause of hormonal irregularities observed in European adolescents (Vogel, 1995, p. 154). This had a significant negative impact on the veal market and strong regulatory action was thought necessary to restore consumer 
confidence and to ensure the proper functioning of the European Single Market (i.e., to avoid market distortions that would arise if some member states imposed bans and other member states did not). The first Directive banning the use of hormones for animal growth promotion purposes was adopted in 1981 (European Council, 1981). DES, the hormone responsible for the initial European concern, was also banned in the US (Vogel, 1995, p. 154). As a result of a July 1981 debate in the European Parliament, the Council of Ministers sponsored a scientific inquiry into the use of five hormones; this investigation found that three posed no health risk and that there were no data for two (trenbolone and zeranol, which studies in 1984 and 1985 found not to pose signficant risk to consumers) (Vogel, 1995, pp. 154-5; Vogel, 1997, p. 15). The US FDA permits use of all five of these hormones (Vogel, 1995, p. 158).

In 1985 the Council of Ministers extended the 1981 Directive to cover these five hormones. The EC's agricultural commissioner, Frans Andriessen, explained that 'Scientific advice is important, but it is not decisive. In public opinion, this is a very delicate issue that has to be dealt with in political terms' (Vogel, 1997, p. 16). The EU also placed a ban on importing beef that had been treated with these hormones as early as 1985. Sir Roy Denman, the then EC Head of Delegation to the US, compared the EC's ban on hormone-treated beef products to US restrictions on the sale of unpasteurized cheese from Europe because of 'health reasons,' arguing that Europe had never demanded a scientific inquiry for this restriction but rather 'accepted that Americans have expressed a democratic preference for hygiene over taste, however eccentric or unnecessary' (Vogel, 1997, p. 18). Europeans also pointed to their restraint in declining to challenge the US ban on Alar despite its questionable scientific basis (Vogel, 1995, p. 163). The EU re-adopted its 'Hormone directive' in 1988, effective January 1989.

In response, the US increased duties on selected European products, but these duties were relaxed while negotiations on a settlement were undertaken. After entry into force of the WTO Agreement on the Application of Sanitary and Phytosanitary Measures (the SPS Agreement) on 1 January 1995, the US and Canada initiated formal dispute resolution procedures against the EU under the WTO (Charnovitz, 2000; Vogel, 1997, pp. 19-21). The US claimed that the European ban adversely affected US exports of meat and meat products, that the EU's measures were not based on an assessment of risk, and that US meat and animals were 'like' EU meat and animals. The US position was that the EU ban was

not based on scientific principles and therefore ... violates the WTO Agreement on the Application of Sanitary and Phytosanitary measures. The United Nations Codex Alimentarius has recently confirmed the lack of a scientific basis for restricting the use of these growth hormones (USTR, 1996).

The US maintained that these hormones pose no risk to human health, stating that

decades of worldwide scientific studies have shown that consumption of beef from animals produced using the six approved growth promoting hormones - estradiol, melengestrol acetate, progesterone, testosterone, trenbolone acetate, and zeranol - does not present a risk to human health. US beef is safe (USTR, 1999).

Further, the US argued that the EU's official 'Opinion' regarding the safety of hormones

is not consistent with numerous scientific reviews conducted by reputable international organizations ... and represents a significant departure from the conclusions reached by all previous international review panels (USTR, 1999). 
The USTR also pointed out that 'hormones occur naturally in many foods. Consumers are exposed every day to foods with higher hormone levels than those found in any beef from animals treated with hormones'; for example, 'hormone levels in beef are far less than those found in eggs,' and 'one bowl of split pea soup has more than nine times as much naturally-occurring estrogen as a five-ounce portion of meat from a steer raised using hormones' (USTR, 1999).

In August 1997, the WTO Dispute Panel found that the EU's ban on US beef and beef products violated the WTO regulations and resulted in an annual loss to the US of $\$ 116.8$ million (World Trade Organization, 1997). This decision was upheld by the WTO Appellate Body in January 1998 (World Trade Organization, 1998; for discussion see Charnovitz, 2000). The final outcome of this trade dispute is still awaited; the US and Canada have imposed trade retaliation measures against Europe and the parties are seeking to negotiate a resolution. The EU continues to defend its position that these growth hormones may be harmful to humans (Charnovitz, 2000, p. 274; Faull, 2000), and the US continues to argue that they are not (USTR, 1999).

Regarding beef hormones, as with BST for milk production, the European approach was more precautionary than the US approach. Questions about Europe's risk management procedures have been raised, but the fundamental issue concerns the extrapolation to low doses, and this remains a major issue for toxicologists. It may not be possible to resolve the low-dose issue to the satisfaction of both sides, and hence the importance of the arguments over the question of whether the US meat was 'like' the EU meat. Nevertheless, research continues to deepen the scientific understanding of the risks to human health associated with the use of growth promotion hormones. The problem is at heart one of scientific uncertainty and the propriety of precautionary action. Both the BST and beef hormones decisions were premised more or less on the precautionary principle. Yet both examples also suggest that other motivations may also have been at work, including domestic economic concerns.

\subsubsection{Bovine Spongiform Encephalopathy (BSE) ('mad cow disease')}

a. BSE in beef. The first case of BSE (or ' $\mathrm{mad}$ cow disease') in the UK occurred in 1985, followed by rapidly increasing numbers of BSE-infected cattle across England (over 2000 cases by 1988). The peak of the UK epidemic occurred in January 1993, with 1000 new cases diagnosed per week. By 1997 there were fewer than 200 cases per week (US FDA, 1997). Between 1985 and 1999, over 160000 cattle died from BSE, and many more were slaughtered before reaching age 5 (the mean incubation period for BSE) (Anderson et al., 1996).

The outbreaks were widespread and almost simultaneous, and hence there seemed to be only one common probable cause: food contamination. Protein of animal origin, including discarded brain and spinal tissue from previously rendered cattle and sheep, had increased from $1 \%$ to $12 \%$ of British cattle feed in the $1980 \mathrm{~s}$, in response to the increasing price of imported soy and fishmeal (Rhodes, 1997). Ironically, it appears to have been the well-intentioned recycling of this otherwise discarded animal material that unwittingly introduced contamination into the cattle feed. Simultaneous changes in the permitted manufacturing methods of cattle feed containing animal protein (among others, permission to use lower processing temperatures) meant that greater numbers of cattle were consuming feed that may have contained the infectious agent of scrapie (a spongiform encephalopathy disease of sheep). 
In 1987, scientists suggested that BSE might be linked to feed containing the scrapie infectious agent, and in 1988 the UK adopted a ban on feeding protein derived from ruminant animals to cattle, and a slaughter policy for infected cattle. In 1989, the UK government set up a scientific panel to advise on the problem. The presumed infectious agent of BSE is the prion, an abnormal protein that somehow stimulates an array of brain diseases including BSE, scrapie, chronic wasting disease, and kuru, and the transmission of which is not prevented by digestion or high heat (Prusiner, 1997). Prions seem to reside only in the brain and spinal cord.

In addition to the affliction of cattle with BSE, there was growing concern that human consumption of BSE-infected cattle products might transmit prions that could then give rise to a human spongiform encephalopathy disease called Creutzfeldt-Jakob Disease (CJD). It is generally accepted that diseased animals should not enter the food chain. However, for a long time the UK government insisted that there was no risk to humans from BSE, although the government did inaugurate a monitoring programme for CJD (see UK, 2000). Ruminants' brain and spinal tissues were not banned from entering the human food chain in the UK until late 1989. The 'no-risk' assumption was based on partial scientific advice; scientists had always argued that a link between BSE and CJD could not be ruled out. Still, the government had accepted the scrapie origin for BSE. This was reassuring with regard to CJD because scrapie had been endemic in British sheep for more than 200 years and had never been linked to CJD. On that basis, BSE (thought to be coming from scrapie) was assumed not to cause CJD.

In the first half of 1990, at least seven countries, including France, West Germany, Italy and Russia, banned the import of British beef. In June 1990, the EU agreed to tighten regulations to prevent the spread of BSE, and in response France, West Germany and Italy agreed to lift their bans. In 1994, the EU decided to loosen its regulations on cattle born after 1 January 1992. On 6 February 1996, five German regional states banned the import of British beef.

On 20 March 1996, the UK Government reported the appearance of a new variant form of CJD ('vCJD'), afflicting young people, and raised the possibility that this vCJD may have come from BSE that spread to humans from eating beef (Goethals et al., 1998). ${ }^{2}$ In the next few days, Germany, France, Belgium, the Netherlands, Portugal, and Sweden adopted temporary bans on British beef (and in some cases on live cattle and beef products as well). On 27 March 1996, one week after the UK report of vCJD was issued, the European Commission banned all exports of beef, live cattle and beef products from the UK in Decision 96/239 (European Commission, 1996).

The UK challenged the Commission Decision of 27 March 1996 (the export ban) in a case before the European Court of Justice. The British argued that the measures that had already been taken by the UK were adequate and thus, in effect, that the export ban was disproportionate; and furthermore that the Commission had exceeded its powers. (The UK's additional measures included banning the sale for human consumption of meat from bovine animals over 30 months old, and banning the use of mammalianderived meat meal and bone meal in feed for any farm animal. Animal slaughter procedures were also made more stringent. The EU adopted a feed ban in 1994.)

2 The number of human vCJD victims remains small - approximately 100 cases between 1996 and 2000 (Lyall, 2000), compared to over 160000 cattle - but the appearance of CJD in young people is very rare; the type of brain damage was different from that of traditional CJD, suggesting that a new human disease might be arising associated with BSE in cattle; and the latency period for manifestation of CJD may be several years, suggesting that additional human cases of vCJD may appear over time. 
The Commission defended on the ground that the precautionary principle (PP) empowered the Commission to take the action that it had taken, and that the action was proportional to the threat. On the first question, the Court made it clear that regulatory bodies have the right to invoke the PP, which means, the Court said, that

where there is uncertainty as to the existence or extent of risks to human health, the institutions may take protective measures without having to wait until the reality and seriousness of those risks become fully apparent.

This statement is essentially version 1 of the PP as described above. (Like version 1, it does not say much, because there is always 'uncertainty . . . as to the extent of risks,' and the reality of risks is never 'fully apparent'; the Court's statement does not address the real question of what measures to take in light of the inevitable uncertainty.) On the second question, the Court ruled that the export ban was not a disproportionate action by the Commission and furthermore reminded the litigants that the measures were temporary pending the results of further scientific studies and the analysis of the significance of new information on vCJD. The Court therefore dismissed the action brought by the UK (UK v. CEC, 1998).

The stringent measures taken by the UK against BSE in the national herd were successful in reducing the incidence of BSE, and within months of its imposition the EU began to lift its ban. On 11 June 1996, the ban on gelatin and semen was lifted, and on 22 June 1996 - only three months after the EU ban on British beef was imposed - European leaders signed the Florence Agreement which outlined a progressive plan to lift the ban. Under this agreement it was not until 10 June 1998 that the export ban was lifted on the next category of beef product - deboned fresh British beef from BSEfree cattle aged between six months and 30 months and born after 1 August 1996. The export ban was eventually fully lifted by the European Commission in Decision 98/692 of November 1998 (European Commission, 1998), which became effective on 1 August 1999. Under the UK's Date Based Export Scheme (DBES), deboned beef and beef products were subsequently exported from the UK.

However, within the EU, France and Germany maintained their import bans, contrary to EU law. The German Federal Government lifted its ban on 17 March 2000. The French government has not lifted its ban. Instead, it produced evidence from the French Food Safety Agency in support of its ban. France noted the increasing sensitivity of tests for prions, allowing the detection of infectivity in tissues where none had previously been found. France also cited a possible slowdown in the rate of decrease of BSE cases in the UK. Other concerns related to the effectiveness of surveillance programs and meat traceability. This evidence was considered by the European Commission's Scientific Steering Committee (SSC), which agreed unanimously that 'there are currently no grounds for revising the overall conclusions of the SSC Opinions directly related to the rationale of the DBES' and that 'the measures taken by the UK make any risk to human health from the UK DBES at least comparable to that in any other European Member State' (European Commission, 1999a).

Following this finding, the European Commission asked France to lift its ban, but France refused. In January 2000, the Commission declined to seek an injunction against France to lift its ban, noting that the European Court of Justice has historically been reluctant to grant injunctions against measures to protect public health. Later in 2000, the Commission decided to seek a court order to require France to adhere to Decision 
98/692 and lift its ban on British beef (European Commission, 1999b). On 13 December 2001, the ECJ ruled in the Commission's favour and ordered France to lift its ban (CEC v. French Republic, 2001).

The situation became more complicated in late 2000, when small but increasing numbers of cases of BSE began to be detected in France and other countries in Europe. A French farmer was arrested in November 2000 for trying to smuggle a diseased cow to market, and the first cases of BSE were detected in Germany and Spain. In response, consumer demand for beef plummeted (Daley, 2000b), several other European countries instituted bans on the import of French beef, France undertook measures (as Britain had earlier) to restrict the use of animal protein in all animal feed and to prevent cattle over 30 months old from being marketed (Minder, 2000), and the EU decided to apply these precautions throughout Europe (Daley, 2000c).

Recently, the British Government promised to pay ex post compensation to vCJD victims and their families. Farmers had already been compensated by the government for the loss of their cattle (Lyall, 2000). Meanwhile, the official Philips Inquiry delivered a stinging criticism of the slow response of the UK government to acknowledge and combat the risks of BSE and vCJD (UK, 2000; Lyall, 2000). A subsequent French parliamentary inquiry also denounced the British and EU policies - and even France's own comparatively aggressive stance - as inadequately precautionary (Daley, 2001).

'Beef on the Bone.' If the British government was reluctant to apply the Precautionary Principle in the early stages of the BSE epidemic (1988-1990), the eventual appearance of cases of vCJD by 1996 resulted in an opposite regulatory tendency. This is most clearly demonstrated by the UK's ban on the sale of 'beef on the bone' from 1997 to 1999.

As part of the investigations of BSE infectivity by the UK Ministry of Agriculture Fisheries and Food (MAFF), it was discovered that positive infectivity was present in nerve tissue connected to the spinal column, namely the dorsal root ganglia (DRG). This tissue was not removed with the spinal cord when the animal was slaughtered and was not covered by the UK regulations specifying those tissues that were banned from human consumption. The DRG were associated with the bones and hence there was a potential risk in the consumption of such beef products as T-bone steaks and rib joints.

MAFF estimated that less than 1 gram of infected nerve tissue could induce BSE in $50 \%$ of an exposed population; that four cattle in 2 million might carry infected DRG tissue; and that about $5 \%$ of the DRG tissue would remain in cuts of beef on the bone. With these inputs, MAFF's probabilistic risk assessment predicted that the total beef consumption of the UK in 1997 would confer a risk equivalent to a 5\% chance of one additional case of vCJD in the entire country per year, or an individual risk of around one in 1 billion per year (Comer, 1998). Of course there were large uncertainties in the analysis, and the results were highly dependent on the assumptions made (many of them tending to overstate the risk). This risk was much less than the chance of being struck by lightning. Nonetheless, the UK Government opted for extreme precaution and banned all sales of beef on the bone until the BSE epidemic had been brought under control.

By taking such a precautionary approach, the government presumably reduced consumer intake of contaminated beef, although ironically the regulations appear to have provoked some outbreaks of risky behaviour: in some sections of the population there seems to have been a wilful desire to increase the consumption of beef on the bone. 'Prohibition' dinners featuring beef on the bone were offered by one hotelier, oxtails were more in demand than before, and butchers flouted the law. Even Professor 
Durant (public understanding of science, Imperial College London) was moved to pronounce the ban farcical (Irwin, 1997). Although the ban on the sale of beef on the bone has now been lifted in the UK, it is still the case that only deboned beef can be exported from the UK under European Commission Decision 98/692.

The US Response to BSE in Beef. By contrast to the meandering path of UK and EU policy as to British beef, the United States acted early and resolutely to bar such imports, even though no cases of BSE had been observed in the US. In 1988, the United States Department of Agriculture (USDA) established a BSE Working Group to evaluate the scientific evidence available on BSE and suggest appropriate responses. On 21 July 1989, the Animal and Plant Health Inspection Service (APHIS) of USDA implemented an import ban on all ruminants and certain cattle products from the UK. On 6 December 1991, APHIS further restricted the importation of ruminant meat, meat products and byproducts from all countries with confirmed cases of BSE (USDA, 1991). APHIS broadened the import ban on 12 December 1997 to include all European countries (USDA, 2000). The US ban on beef imports remains in effect.

In addition, because rendered animal products used in animal feed may be the common source of infection of transmissible spongiform encephalopathies (TSEs), the US FDA adopted a domestic ban prohibiting the feeding of ruminant and mink protein to ruminant animals which became effective on 4 August 1997 (US FDA, 1998). This prohibition became effective nine years after the UK prohibition on the use of mammalian protein in the manufacture of feed for ruminants and three years after a similar policy was adopted by the EU, but a voluntary moratorium on mammalian protein in feed had been in effect in the US for most of that period.

The USDA decision to ban BSE-affected beef is avowedly precautionary:

The USDA policy has been to be proactive and preventative. APHIS has taken measures in surveillance, prevention, education, and response. Import restrictions have been in place since 1989, and active surveillance efforts began in 1990. The USDA continually monitors and assesses all ongoing events and research findings regarding spongiform encephalopathies, as new information and knowledge may lead to revised conclusions and prevention measures. APHIS has also created a Transmissible Spongiform Encephalopathy (TSE) Working Group to analyse risks of BSE to the United States, disseminate accurate information about the TSEs, and act as a reference source for responding to questions about TSEs (USDA, 2000).

As of 12 December 1997, APHIS has prohibited the importation of live ruminants and most ruminant products from all of Europe until a thorough assessment of the risks can be made. (USDA, 2000).

This action was taken in the past year because the Netherlands, Belgium, and Luxembourg have reported their first cases of BSE in native-born cattle. There is evidence that European countries may have had high BSE risk factors for several years and less-than-adequate surveillance. Additionally, Belgium reported that a cow diagnosed with BSE was processed into the animal food chain. This science-based decision was made to protect human and animal health, to ensure the security of US export markets, and to shield the safety and the integrity of our food supply (USDA, 2000).

Summary. While Britain observed thousands of cases of BSE in the 1980s, it continued to export beef. The EU waited to adopt its ban on British beef until 1996, lifted that ban in phases between 1996 and 1999, and then pressed France to lift her remaining 
ban. Meanwhile, with zero domestic cases of BSE, the US imposed its ban on British beef in 1989, broadened it to cover several countries, and continues that ban in effect today. As to imports of beef, the US acted more quickly in the face of uncertain risk, while the UK and EU spent more time conducting detailed risk assessments and ultimately imposed only temporary restrictions. Meanwhile, both the US and UK banned mammalian protein in the feed for ruminants, but here the US was slower to formalize that ban: the UK banned feeding animal meal to cattle in 1988 while the US did not do so until 1997.

b. BSE in blood donations. A further concern about BSE is that it might be transmitted not only by eating beef, but by transfusions of blood from people who had eaten contaminated beef. It has long been known that spongiform encephalopathy diseases could be transmitted through dura mater (brain covering) grafts, contaminated supplies of human growth hormone, and cannibalism in which victims' brain tissue is eaten (the source of kuru). But the risk that TSE could be transmitted via ordinary blood transfusions from people who had eaten BSE-contaminated beef was a highly uncertain conjecture. Nonetheless, acting on that concern, in August 1999 the US FDA instructed blood banks (such as the American Red Cross) to reject blood from any donor who had spent more than six months cumulative in the UK during the years 1980-1996 (the period of the BSE epidemic) (US FDA, 1999c). In June 2001 the FDA proposed to go further, rejecting any donor who had spent three months or more in the UK or five years or more anywhere in Europe since 1980 (Hernandez, 2001).

The FDA officially titled this regulation a 'Precautionary Measure.' It acted despite recognizing that there have been no studies showing human blood transmission of CJD, only conflicting animal data, and no cases yet of vCJD in the US; that the 'transmissibility of vCJD by blood or blood products is unknown' and the 'transmissibility [of vCJD] cannot confidently be predicted from studies of CJD'; and that 'No transmission of CJD or vCJD by human blood components or plasma derivatives has been documented to date' (US FDA, 1999c). European officials considered the risk 'theoretical' and 'very small' at the most (Tagliabue, 2001). But FDA said that

Until more is known about the possibility of vCJD transmission by blood components or plasma derivatives, a precautionary policy of withdrawal for all of these products is recommended for material from donors with vCJD (US FDA, 1999c).

FDA banned blood from all donors who had spent at least six (later, three) months in the UK, not just from those who had eaten British beef; and FDA added no question to be asked of donors about their beef intake.

The boldness of this precautionary move is evident from the countervailing risk it creates: a shortage of blood for use in hospital operating rooms. The American blood supply is already very tight. The Red Cross testified to the FDA that the 1999 policy would likely reduce the pool of eligible blood donors by about 2\% (US FDA, 1999d), and the 2001 policy would reduce the blood supply by 5-8\% (Tagliabue, 2001). Blood shortages would be severe in New York City: in addition to losing 8\% of its American donors, New York would lose the $25 \%$ of its blood supply that is imported from European donors who would be banned under the 2001 policy (Tagliabue, 2001). These reductions in blood supply pose a high and fairly certain risk of death to those who need emergency blood during operations - in New York, a 'disastrous . . p public health 
crisis' (Tagliabue, 2001). And the restrictions increase the risk of other contaminants affecting the blood supply (such as hepatitis and other blood-borne illnesses), because collection organizations will have to replace oft-tested repeat donors with new donors who may harbour risk factors that the screening tests do not always detect (i.e., false negatives).

The FDA policy may have been motivated by recent concern about AIDS in the US and French blood supplies in the 1980s. French officials were eventually convicted of crimes for inadequately screening HIV-contaminated blood. In a combination of the 'availability' heuristic (overstatement of the risk of similar recent incidents) and the regulator's reputational incentive to avoid false negatives, this recent history may have encouraged FDA to be especially precautionary about the next disease to threaten the blood supply, even remotely (cf. Sunstein and Kuran 1999).

Canada adopted a ban on blood donors who had spent six months or more in the UK during 1980-1996 (Stecklow, 1999). This ban was expected to exclude 3-4\% of donors; one employee of the Canadian Blood Supply predicted a 10-15\% decline in blood supply (Toronto Sun, 1999), presumably because the Canadian donors who visit the UK are especially significant donors. In August 2000, Canada extended the blood ban to include people who have spent six months or more in France (Blanchfield, 2000).

By contrast, on 23 February 2000, France announced that it would not ban blood donations from those who had travelled to Britain during the mad cow crisis, citing a shortage of blood supplies (Bilefsky, 2000). This is especially noteworthy because it was France that had suffered the most dramatic cases of HIV contamination in the blood supply.

If the UK were to be as precautionary as the US and Canada, it would at least have to ban all blood donations by its own citizens (as well as by those foreigners who had visited the UK for over six months during 1980-1996). The impact on the blood supply in the UK would be severe. Of course, the UK did not do this. In July 1998, Britain began to implement a programme to purify its blood supply by 'leukodepletion' removing white blood cells from donated blood as a protective measure against vCJD (Reaney, 1998a). In addition, beginning in February of 1998, government funded health services were authorized to import blood plasma (Reaney, 1998b).

Recent research suggests that it might be possible for BSE to be passed on by blood transfusions (Bostock, 2000). Scientists infected sheep with BSE and, before encephalopathy symptoms appeared, took blood from the infected animals and transfused it into healthy sheep. The preliminary research results indicated that one of the transfused sheep has begun to exhibit signs of BSE. The research programme will not be complete for several more years. These preliminary results were followed by three related stories. The first reported that seven people who had subsequently developed vCJD had donated blood, and that some of the blood from these donors had been mixed with the blood of other donors before distribution to hospitals (Leake, 2000). (These donations occurred before the beginning of leukodepletion procedures in 1998.) The second story concerned vertical transmission in humans (Rumbelow, 2000). A baby whose mother died of vCJD seems to be showing symptoms of the same disease. Diagnosis of vCJD can only be certain after death, but since vertical transmission of BSE occurs in cattle, it does not seem unlikely that vertical transmission will eventually be found in humans, and this may well be the first case. Third, prion research has indicated that it is possible for prion replication to occur in laboratory animals without those animals 
manifesting disease symptoms (Hill et al., 2000). This opens the possibility of asymptomatic carriers of TSEs, and hence the risk of transmission from apparently healthy donors - and of course amplifies the risks of exposure to BSE through ingestion of food products from apparently healthy animals. Additional research suggests that prions might be transmitted - and also detected - in dried urine (Blakeslee, 2001).

Taken together, the supporting evidence for the blood safety precautions taken by the US, Canada and recently New Zealand is increasing. By any estimate the risk of blood-borne BSE is very low, but one could not say that it is zero. The US and Canada appear to be taking a much more precautionary approach toward BSE and vCJD in the blood supply than are the UK or France. The reluctance of France and the UK to restrict the blood supply derives precisely from concern about the countervailing health risks of doing so. Even in the US, the FDA initially chose the 'six months in Britain' criterion, rather than a shorter time period or a criterion of 'ate British beef,' because the FDA feared exacerbating the blood shortage by turning away too many donors. Yet there is little evidence that any of these governments has carefully analyzed and weighed the conflicting risks of BSE and $\mathrm{VCJD}$ versus the risks of worsened blood shortages.

\section{Explaining the complex pattern}

The above analysis indicates that the conventional wisdom of a precautionary Europe and a risky America (or a general 'flip-flop' in relative precaution across the Atlantic) is unpersuasive. The claim that Europe is now generally more precautionary than the US, or even trending in that direction, appears to rest on selective emphasis of particular examples, such as hormones in beef and genetically modified foods. This claim does not match up well against a larger sample of regulatory laws. Even in the area of food safety, which is often cited as a flagship of European precaution, the US has been more precautionary than Europe on important recent examples such as mad cow disease (BSE) in beef and especially in blood. More generally, neither the EU nor the US has been consistently more adherent to the precautionary principle, whether viewed over the last five years or the last 30 years. The reality is a complex and mixed pattern over both space and time. Relative precaution seems to depend at least as much on the risk as on the country or the time period.

What accounts for the complex reality that the more precautionary actor is sometimes the EU, and sometimes the US? Many theories have been offered to explain regulatory policies within one country, among them public interest theory, public choice theory, civic republican theory, and the application of cognitive psychology theories (Schroeder, 1998; Sunstein and Kuran, 1999). No one of these provides a complete account of risk regulation in the United States (Wiener, 1999). Trying to compare several regulatory decisions across two different polities magnifies the weakness of single theories, especially when each polity is highly variegated and substructured internally as well. Moreover, the outcome we are observing and attempting to explain - regulatory lawmaking - is highly sensitive to unobserved political contingencies and coincidences. Thus, no single 'thick' theory is likely to explain fully the complex international pattern in relative precaution. Perhaps no coherent explanation can be given. So many different variables are at play, so many different risks are being addressed (by so many different institutions), and so many different societies are being 
studied, that a pluralist approach seems essential. Therefore, we do not propose a single magic answer. Instead, we examine an array of potential explanatory hypotheses and we offer some evaluations of each. We find that none of the hypotheses fully accounts for the complex pattern, but several in concert may be illuminating.

\subsection{TAILORING ON THE MERITS}

One possible explanation, in the vein of the public interest theory of regulation, is that each society has made a different but reasoned judgment about the merits of precaution as to each risk. There can be good reasons to be precautionary, including the risk of false negatives, the risk of low probability but high impact events, the problem of long latency, and the lack of a contingency regime in case an adverse event does occur. On the other hand, there can be good reasons to be circumspect about precaution, including the risk of false positives, cost, the value of obtaining additional information (versus the cost of delay), risk-risk tradeoffs, restrictions on individual freedom, and the availability of ex post legal regimes (such as monitoring of products on the market, and tort law to deal with the residual injuries that arise even after ex ante regulation is imposed). Perhaps the US and EU have each evaluated this set of factors and come to a judgment about how to tailor regulatory law to achieve the optimal balance in each case. The optimal result on each side of the Atlantic may be different because of different social, economic, and cultural factors. For example, European populations may be more susceptible to some risks and American populations more susceptible to others. Or the different populations may place different valuations on avoiding different risks and these different valuations may change over time. Clearly, the costs of avoiding different risks may vary (e.g. perhaps the EU was slow to regulate BSE in beef and in blood because the costs of such regulations would be high there, whereas it was easier for the US to take those actions). Or the ex post regimes for monitoring and sanctioning residual risks may vary.

All this may be so, but it is difficult to discern such tailoring from the regulatory results. Neither the US nor the EU has taken a consistent position about its own stance. Each has been sometimes precautionary, sometimes not. Worse, each has engaged in the other's ostensibly favoured approach even when the merits seemed to point the other way: examples include potentially excessive US precaution on BSE in blood, and apparently inadequate European precaution on BSE in beef. Yet neither side has offered the kind of case-specific analysis of risks, susceptibility, side effects, valuations, and costs that would persuade observers of the merits of each decision.

Perhaps the inconsistency reflects the disaggregated nature of government. There may be no one US or EU position on precaution because different agencies are making different judgments in different cases. Each agency acts under its own statute (or several statutes), and each member state of the US and EU has considerable regulatory autonomy. Still, on particular issues such as beef, there are seemingly opposite responses by counterpart agencies on closely related questions.

More generally, the pattern may be complex because rational judgment under uncertainty is always difficult. Achieving a consensus within a country is difficult and may involve reliance not so much on rationality as on 'rationalistic illusions' (Funtowicz and Ravetz, 1990). A fortiori, we should not be surprised by the difficulty in obtaining consensus across different countries and at different times. 


\subsection{POLITICAL ADVOCACY}

Some assert that the alleged 'flip-flop' in relative precaution derives from cyclical political changes (Lofstedt and Vogel, 2001). The allegedly greater precaution in the US in the 1970s and 1980s was attributed in part to the greater openness of the US legal system to influence by environmental advocacy groups, through political lobbying, sunshine laws such as FOIA and FACA, notice and comment rulemaking, litigation to challenge agency actions, citizen suits, and other avenues (Lynch and Vogel, 2000). The argument that the EU has become more precautionary than the US since the 1980s is now attributed in part to the efforts of Ronald Reagan and Newt Gingrich to hold back US environmental activism while European environmental groups and Green Parties were gaining strength (Lynch and Vogel, 2000; Vogel, 2001b). (Meanwhile, perhaps the relative absence of formal avenues of influence encouraged European advocacy groups to turn to mass public responses, while the formal openness of the US system invited American advocacy groups to become more litigious and less populist - to work within the system rather than against it.) It is not clear, however, why there should be such cycles in regulatory activity. Important environmental initiatives such as the 1990 Clean Air Act and the entire Clinton-Gore administration are elided. Larger influences on political demand for environmental protection, such as rising incomes, are not addressed. Nor is it clear why, if there are such political cycles, the US and EU should be travelling on alternating waves instead of in tandem or on converging paths. Most theories of the effects of environmental advocacy groups on regulation suggest that increasingly transnational networks act to mobilize simultaneous or converging policy changes (Robinson, 1997; Slaughter, 2000), not alternating cycles. Similarly, the theory of 'legal borrowing' suggests that countries often imitate each other's legal rules (Watson, 1993), and there is evidence of such under way in regulatory law between the US and the EU (Bignami, 1999). Some of the writing by adherents of the flip-flop hypothesis has begun to speak instead about 'convergence' toward a common degree of precaution (e.g. Cadot and Vogel, 2001). Notions of 'regulatory cycles' or a political flip-flop may be more a heuristic than a robust explanation of reality.

Moreover, the political situation of advocacy groups does not seem sufficiently broad or deep to justify the flip-flop hypothesis. Why, for example, were US environmental groups impeded by the Reagan administration, but European environmental groups not impeded by the Thatcher and Kohl administrations? Why were US environmental laws so prolific and robust in the late 1960s and early 1970s, when the US environmental advocacy groups were fledgling at best?

The different political systems of the US and Europe may help explain the opportunity, if not the root cause, for the rise of a more precautionary perspective in Europe. European electoral systems are more open to small parties because they employ proportional representation; in the US, winner-take-all elections inhibit third parties. Thus the Green parties in Europe have gained seats in parliaments (including the European Parliament) and sometimes have been partners in governing coalitions (including in Germany, France and Belgium) (Lynch and Vogel, 2000). By contrast, third parties in the US (such as the Green and Reform parties) hold no seats in the Congress and may never win the Presidency. On this view, the voting systems in Europe have over time opened the door to greater voice for precautionary politics than would occur in the US. 
On the other hand, it is also argued that regulatory policies in Europe tend to be made more by political elites, whereas these policies tend to be more driven by mass public attitudes in the US (Lofstedt and Vogel, 2001). On this view, it is the attitude of these elites that explains both the European affinity for stringent environmental precaution and the European aversion to stringent criminal punishments. In the US, on this view, perhaps the public's demands are reflected in initially stringent but now ebbing environmental regulations, and in increasingly stringent criminal laws. These conjectures, of course, are immediately open to question. One wonders exactly who these 'elites' are in Europe (and who 'the public' is in the US) and why they want what they want. And the more populist system asserted to characterize the US is just as often thought to give rise to more stringent environmental regulations than an eliterun system, not less (Breyer, 1993; Shrader-Frechette, 1991).

In any case, the flip-flop image would predict greater precaution by the EU than by the US in the 1990s, and yet this is not the pattern observed. The real examples of relative precaution do not seem to fit the political shift hypothesis. Large shifts in environmental group or green party power, even if true, seem too broad to explain the complex mix of regulatory approaches over time. True, the US enacted much important environmental legislation in the 1970s, but several of these statutes operate on benefit-cost principles (e.g. the Toxic Substances Control Act and the Consumer Product Safety Act). Meanwhile it was in the 1970s that Europe was explicitly adopting the precautionary principle (Boehmer-Christiansen, 1994). True, US environmental law did face challenges from the Reagan administration (though the sharpest challenges were limited to 1980-1982), but the US nonetheless enacted highly precautionary statutes during the 1980s and early 1990s, such as the Superfund amendments of 1986, the Oil Pollution Act of 1990, and the Clean Air Act Amendments of 1990 (and the lead phasedown and CFC phaseout were also accomplished during those years). The innovations introduced in US environmental law in the 1990s, such as the use of the cap-and-trade system in the 1990 Clean Air Act to control acid rain, the revision of the Delaney Clause in the Food Quality Protection Act in 1996, and the revision of the Safe Drinking Water Act in 1996 (all by large bipartisan majorities), seem to reflect learning rather than setback, and may well prove to be more, not less, protective of the environment. Meanwhile, the US was more precautionary than Europe on several major topics during the 1980s and 1990s, including the phaseout of lead in gasoline and the BSE-motivated bans on beef and blood donations. And although the EU has certainly accelerated its environmental regulatory activities in the 1990s, and was more precautionary than the US on rBST and on genetically modified foods, Europe has been less precautionary in recent years on such examples as BSE-tainted blood donations. Thus, the examples arrayed over time do not seem to bear out a generalized switch in the relative politics of transatlantic precaution.

\subsection{RISK PERCEPTIONS}

Perhaps specific regulatory responses are driven by public attitudes, and those public attitudes about specific risks are different in the US and Europe. Perceptions of risk may be influenced by both cognitive errors and value choices. Among the sources of public risk perceptions that may be relevant to the comparison of American and European regulations are dread of the unfamiliar, the availability heuristic, distrust of government, and culture. 


\subsubsection{Familarity and dread}

Risks seen as familiar, natural, and voluntary tend to be viewed as more acceptable than risks seen as unfamiliar, unnatural or involuntary (Slovic, 1987). Perhaps the European public now exhibits a greater 'fear of the unknown' than do Americans, leading, for example, to more precautionary regulation in Europe of GMOs. Yet the US has been more precautionary than Europe about other 'unknowns,' such as prions in blood and nuclear power, while Europe has often regulated well-known risks such as guns more stringently than has the US. Survey research suggests that the divergence between US and European policies regarding nuclear power is not explained by differences in public fears, because Europeans and Americans are similarly fearful of nuclear power (Karpowicz-Lazreg and Mullet, 1993; Slovic et al., 2000). Perhaps Europeans resist GMO foods and rBST because these technologies are seen as unnatural. For example, European consumers may be more closely attached to getting their food from small local farms, while American consumers may be more comfortable with large hightechnology farming and mass-market distribution. The pattern of environmental regulation over time and across countries might be explained in part by changing conceptions of what is 'natural' and efforts to legislate protection of that 'natural' state against the taint of 'unnatural' human disturbance (Wiener, 1995). What is deemed 'natural' and 'unnatural' may differ between Europe and the US (as well as internally within each).

\subsubsection{Availability}

The 'availability' heuristic suggests that people will give greater weight to a risk which is fresh in their minds, often because of a recently publicized incident (Sunstein and Kuran, 1999). Put another way, an uncertain risk may seem more foreseeable to a party who has had more recent experience with another similar risk, even if the two risks are not causally related. Such awareness may also be heightened by news media attention. If the public responds particularly to recent incidents rather than to future probabilities, then risk regulation may be buffeted by episodes of public clamoring which are out of proportion to the expected social harm at issue, and which neglect the risks of greater future importance. Perhaps people in European have responded more intensely to hormones in beef, including rBST, because of the reported incidents of illness among Italian children who consumed DES. And perhaps the European resistance to genetically engineered foods derives in part from recent concern about BSE and other contaminants in food, even though the two may not be scientifically connected. Perhaps the aggressive US posture to BSE in blood donations relates to publicity about HIV. But HIV in blood has been a major issue in Europe as well (particularly in France), yet European restrictions on BSE in blood have not been nearly as aggressive as those in the US. Nor does the availability heuristic explain the relatively sluggish UK response to BSE.

\subsubsection{Distrust}

Distrust of government can magnify public fears of a risk (Slovic et al., 1991). The perceived mishandling of the BSE epidemic, as well as the scandal of AIDS in blood in France and other events may have led the European public to distrust government assertions that rBST or genetically engineered foods represent low risks (Lofstedt and Vogel, 
2001). On the other hand, distrust does not seem to account for the stringent US stance on BSE in beef and blood. And in general the US, more than Europe, is thought to have a political culture that distrusts government (Nye et al., 1997).

\subsubsection{Cultural origins}

One might try to find deeper cultural underpinnings to the differences in risk perceptions between the US and Europe. Perhaps America has always attracted risk-takers leaving Europe and elsewhere to seek opportunity, while Europe has retained a higher proportion of people who are risk averse. This view may be consistent with the history of immigration to the US from Europe, with the frontier ethic in America, and with the apparently widespread view in Europe that America is uncivilized, violent and commercially cutthroat (Daley, 2000a; McNeil, 2000). But this view is not consistent with the observed evidence that on many risks the US has been more precautionary than Europe (at least in the 1970s, if not more recently).

\subsubsection{Future research}

Insights from cognitive psychology may be helpful here, but there are too few data to make any real claims. There is a rich empirical literature on risk perceptions in the US, and a growing literature on risk perceptions in Europe. There is a significant need for comparative risk perception studies, asking the same questions of respondents in both the US and Europe. Some of that work is now being undertaken; it emphasizes differences between psychological and cultural approaches to comparing risk perceptions (e.g. Renn and Rohrmann, 2000; Weber and Hsee, 2000).

\subsection{PROTECTING DOMESTIC INTERESTS}

Perhaps relative precaution in the US and Europe derives from factors other than a desire to prevent health and environmental risk. Europeans may fear globalization, especially if globalization means Americanization, and therefore may resist new products from the US. In particular, economic protectionism may explain some of the complex pattern of relative precaution.

The EU may be seeking to protect agricultural trade, such as by excluding US beef hormones, rBST and genetically engineered foods, but nonetheless allowing purchases of British beef despite the residual risk of BSE. As noted earlier, some EU officials were explicit that the bans on hormones and rBST were for economic reasons - to protect the internal European market and to shield small farmers - and not for health reasons. The WTO made a similar finding. Meanwhile, the US may be trying to foster exports of its agribusiness products (including hormone-fed beef, rBST, and genetically engineered foods), while excluding British beef.

Trade rivalry may also play a role in global environmental treaty negotiations. The US apparently did weigh international competitiveness concerns in its deliberations over the Montreal Protocol: it decided to back the phaseout in part because US producers saw a lead over foreign competitors in CFC-substitutes (Litfin, 1994; Wiener, 1999). Europe may be making a similar calculation about seeking higher targets for greenhouse gas emissions reductions: such targets, especially with curbs on the global emissions trading sought by the US, may impose higher costs on the US and Japan than on Europe (Wiener, 1999). And perhaps US restrictions on European blood 
donations might be explained as an effort by the Red Cross to exclude imports and restrict supply so as to drive up the price that hospitals pay for blood (yet this hypothesis is weakened by the fact that the Red Cross has simultaneously been resisting FDA efforts to tighten other safety rules). These may be examples of attempts at 'predation by regulation' in which regulation is sought by one faction in an industry, not to protect the environment, but to impose higher costs on competitors (Bartel and Thomas, 1987). But the extrapolation of such motivations from industry lobbyists to national government decisionmakers is not always accurate.

Pending further empirical analysis, we are hesitant to explain relative precaution in terms of international economic competition. There is little of an iterative strategic game (such as tit-for-tat or a 'race to the bottom' or 'race to the top') between the US and EU. Much of US and EU precautionary regulation seems largely inward-looking; the international trade disputes that have arisen may only be occasional frictions at the perimeter of a more important domestic policy debate. Many examples of relative precaution seem unmotivated by trade rivalry, including measures regarding blood donations, youth violence, gun control, highway speed limits, and the US ban on CFCs in aerosol spray cans. To be sure, some precautionary restrictions can have major impacts on international trade, but that does not mean that the trade implications are motivating the regulatory restrictions.

\subsection{LEGAL SYSTEMS}

Differences in the legal systems of the US and Europe may also play a role in the different uses and meanings of the precautionary principle. As noted above, the different electoral systems may play a role in enabling Green parties to influence governance. Here five additional aspects of the legal systems are suggested, recognizing that neither European nor American legal systems are internally uniform.

First, relative advocacy of the precautionary principle may be influenced by the relative credibility of national legal commitments. The openness of US law to citizen advocacy groups, judicial review, and science-based adversarialism may make the US more likely to enforce such precautionary measures as are adopted (Jasanoff, 1986; Kagan, 2001; Rose-Ackerman, 1985). This feature of American law may help explain the resistance of the US to adopting strong versions of the precautionary principle in international treaty negotiations: precisely because the US legal system is more likely to enforce treaty provisions on precaution - through citizen suits, judicial review, and direct legislative and executive implementation (Glennon and Stewart, 1998) - the US government may be more reluctant to agree to precaution in international fora. The EU, having already adopted precaution in its own treaties, and knowing that its domestic legal systems are less likely than US courts to enforce such language stringently (Sand, 2000), in part because of judicial moderation and in part because of the historically lower profile of citizen advocacy groups and courts in European law, may be more comfortable with signing on to strong precautionary language. This, in turn, magnifies the US anxiety that Europe will not actually do what the US has agreed to do, further eroding the basis for adopting a common statement of the PP in an international agreement. Put another way, US and European negotiators may be reading the same precautionary text in two very different ways: the US as enforceable law, and Europe as more hortatory rhetoric. This difference in envisioned legal consequences, rather 
than a difference in aspirations for protection of public health and the environment, may help explain the differences in willingness to espouse the precautionary principle.

Second, precaution and ex post remedies may be interrelated in different ways in the US and Europe (and as to different risks). Better mutual understanding of each country's domestic legal systems might help bridge this gap. For example, ex ante precaution may be greater where ex post remedies against private firms are weaker. The generally stronger US system of tort law may make ex ante precaution a less urgent social device in the US than in Europe, where ex post remedies tend to be weaker. Thus US reluctance to agree to stringent versions of precaution may reflect confidence in the US legal system taken as a whole - not opposition to protecting health and the environment. And European advocacy of stringent versions of precaution may reflect an implicit assumption that, in the absence of strong ex post tort liability, ex ante regulation is the only real bulwark between risks and the public - not advocacy of draconian overregulation. (The exception of more precautionary US regulation regarding BSE in blood may reflect the unusual immunity from tort liability granted to blood banks in almost all US states, whereas the ex post remedies for blood contamination may be stronger in Europe.)

A twist on this tort-regulation interaction is that ex ante precaution may be greater where ex post remedies against the regulator are stronger. Although the US may have a more vigorous tort liability system overall, the US has a special doctrine immunizing government policymaking from tort liability, which some European governments and the EU institutions do not. Thus European regulators may seek to employ stringent ex ante regulation in order to shield themselves from lawsuits that could be filed against them if they left small risks unregulated. The contamination of blood with AIDS in France, and subsequent prosecution of French regulators, is a case in point - perhaps acting as an 'availability heuristic' for regulators facing BSE. (But this theory fails to explain the US FDA's highly precautionary regulation of BSE in blood, because under the US doctrine of sovereign immunity for discretionary policies the FDA probably could not be sued if it allowed BSE to contaminate blood in order to avoid blood shortages.)

Third, the difference between the EU legislative system and the American separation of powers system may be important. The European Commission negotiates on behalf of its member states, and ministers of the member states' parliaments know that they represent the party in power in their home legislatures. By contrast, US negotiators know that they may well face a hostile Congress at home, perhaps controlled by the opposition party. Hence US negotiators may be more wary of bringing precautionary language back for ratification than are European negotiators.

A fourth point is that in Europe, the precautionary principle is understood in tandem with the principle of proportionality (Jackson, 1999; Emiliou, 1996). The US has no general principle of proportionality in regulatory law, though some are trying to find it in the 'arbitrary and capricious' test of the Administrative Procedure Act (and 'proportionality' does crop up in American law regarding state restrictions on interstate commerce, self-defense against violence, and other areas). Thus it may be that the US worries that agreeing to the PP could mandate disproportionate, stringent and hasty regulation, while Europe assumes that it can rely on proportionality to moderate precaution. More generally, the US Constitution has few or no general 'principles' of affirmative government responsibility to act. Instead it delegates enumerated powers to 
the federal government, and then recognizes individual rights against government action. European law may be more comfortable than is American law with the notion of overarching affirmative principles, of which the precautionary principle is just one example.

Fifth, the debate over precaution may be serving a role in managing the internal legal hierarchy of each system. The EU may be consolidating while the US is devolving. The European Commission may be trying to use its interpretation of the precautionary principle as a way to foster its legitimacy and/or the Single European Market. For example, the dispute over BSE reflects not just the initial EU and US trade sanctions against Britain, but also the subsequent effort by the EU to insist that all member states conform to the EU's revised policy allowing trade in British beef, and more recently, to impose consistent restrictions on animal feed in all member states. Hence the European Commission's 'Communication' on the precautionary principle (European Commission, 2000) - which attempts to define precaution with several moderating qualifications - may have been directed as much toward winning the internal battles of risk regulation within the EU, rather than the external battles with the US. By contrast, the US may be resisting blanket principles such as the PP because it already has a highly centralized regulatory system and is in a period of debating whether to afford its member states more autonomy in setting regulatory standards. ${ }^{3}$ For this reason, the US may approach precaution case by case rather than as a categorical principle.

These several legal differences between the US and Europe suggest some reasons why the EU might publicly espouse the precautionary principle more eagerly than does the US, even if US regulation is as or more precautionary than European regulation in actual practice. This suggests one possible reason for the conventional wisdom on relative precaution: confusing rhetoric with implementation. But the legal system differences do not correspond to a general switch in relative transatlantic precaution over time. Nor do the legal system differences fully explain the complex pattern of relative precaution with respect to specific risks in practice, such as rBST and BSE.

\section{Conclusions}

The central conclusion of this article is that there is much variation and even inconsistency in the relative precaution exhibited by US and European regulatory policies over time. There is no single or simple basis on which the relative precaution of the US and Europe can be categorically compared. Contrary to the conventional wisdom (based on a narrow sample), we find that across a broader range of cases the EU is not systematically more precautionary than the US. Nor have the US and EU 'flipflopped' over time. Nor can we say that the EU has been more precautionary about, say, food safety than the US; our detailed examination of the case of beef reveals greater European precaution about hormones in beef but greater US precaution about mad cow disease in beef and in blood. Each actor has been more precautionary than the other as to some risks and less precautionary as to others. The degree of precaution exhibited appears to depend less on some overarching national regulatory posture, and more on the context of the particular case: the risk, the technology, the location, the era, the politics, the public, the agency, the legal system. Perhaps, given contingent

\footnotetext{
${ }^{3}$ If in the future the US Supreme Court further restricts the national government's power to regulate risks under the affirmative commerce clause, then agreeing to precautionary standards for risk regulation in an international treaty might become a more attractive avenue to the US Executive Branch.
} 
episodic politics sparked by availability heuristics, the pattern may even be random or chaotic. Rather than attempting to characterize one country as 'more precautionary' than the other, and looking for systemic factors that distinguish all US regulation from all European regulation, we should be investigating relative precaution as a function of the contextual variables with respect to each risk. This research would develop a better understanding of comparative public law, comparative regulatory systems, comparative regulatory politics, and comparative risk perceptions, both across countries and across issue areas.

These observations suggest several lessons about the international debate over the precautionary principle. First, there can be a significant difference between rhetoric and reality. The apparent divergence between the US and EU in advocacy of precaution must be tempered by an understanding of the reality of application across cases, and of the reality of the different legal, political, cultural and economic contexts on each side of the Atlantic. The reality is complexity, not coherence. Moreover, even as the US and Europe dispute who is more precautionary than the other, from a global viewpoint both the US and Europe are probably at the highly precautionary end of the spectrum compared to the rest of the world. The acrimony over precaution between the US and Europe may be driven less by real differences over regulatory philosophy than by a larger contest for great power leadership after the Cold War (Daalder, 2001). Or it may merely reflect the overstated distinctions and competitive strategies between social groups that psychologists have frequently observed people assert, even when people are sorted into groups at random (Horowitz, 2000, pp. 144-7; Tajfel, 1970).

Second, the claim that the precautionary principle is ripening into a tenet of customary international law needs qualification. Customary international law derives from state practice, but here the record suggests inconsistent state practice, both across countries and within advocate countries. Not only have the US and Europe adopted varying positions as to different risks, as shown here, but some countries have simultaneously championed the precautionary principle regarding risks they face from neighbours while rejecting the precautionary principle regarding risks they pose to others (Sand, 2000).

Third, the contest to crown the US or the EU as 'more precautionary than thou' is not only factually misleading, it is also deleterious to sound regulatory policy. A 'race to precaution' could be undesirable for both sides. To be sure, regulatory cooperation on health and environmental risks may be desirable, in order to remove trade barriers, avoid a 'race to the bottom,' and adopt better regulatory approaches built on experience with past regimes. The potential convergence of US principles of risk-based regulation (e.g. Clinton, 1993) and the European Commission's Communication on the Precautionary Principle (European Commission, 2000) may offer hope in this regard. On the other hand, some diversity in regulation can be healthy - it can respond better to local benefits and costs, and it can furnish a laboratory of experimentation that offers insights for continuous improvement. We would not urge a race to harmonize 'up' toward adoption of the most aggressive versions of the precautionary principle, because there are real hazards of excessive precaution: false positives, cost, innovation, and riskrisk tradeoffs. At the same time, we would not urge harmonization 'down' to the lowest common denominator, because there are real hazards to reactive regulation: false negatives, delay, and hence unabated target risks. Instead of a race to be precautionary, or a debate over national precaution across the board, governments should seek to design 
and apply constructive and contextual regulatory strategies. We should neither ignore uncertain risks, nor overreact; but rather seek 'risk-superior' ways of reducing those risks without worsening countervailing risks (Graham and Wiener, 1995). The goal should be a form of 'prudent precaution' that addresses both the risks of inaction and the risks of action.

\section{Acknowledgements}

The authors are grateful for helpful comments from Sara Beale, Rick Belzer, Herbert Bernstein, Francesca Bignami, Gail Charnley, Steve Charnovitz, Phil Cook, Don Elliott, Barry Feld, Baruch Fischhoff, Ilya Fischhoff, William Floyd, John Graham, George Gray, Jim Hammitt, Don Horowitz, Robert Keohane, Ragnar Lofstedt, Richard Merrill, Jeff Rachlinski, Peter Sand, Greg Shaffer, Richard Stewart, Christopher Stone, Cass Sunstein, participants in the Conference on 'The US, the EU and Precaution' in Bruges Belgium, and participants in workshops at the AAAS, the Toxicology Forum, Cornell University, Vanderbilt University, and Duke University. The authors thank Salwa Elshazly, Amy Horner, David Jones, Leah Russin, Emily Schilling, and Nicolle Snyder for excellent research assistance.

\section{References}

Anderson, R.M. Donnelly, C.A., Fergusen, N.M., Woolhouse, M.E.J., Watt, C.J., Udy, H.J., MaWhinney, S., Dunstan, S.P., Southwood, T.R.E., Wilesmith, J.W., Ryan, J.B.M., Hoinville, L.J., Hillerton, J.E., Austin, A.R., and Wells, G.A.H. (1996) Transmission dynamics and epidemiology of BSE in British cattle, Nature 382, 779-88.

Bangemann M. (1993) 'Key note address to the Bio-Europe '93 Conference', Brussels, 1-6 June, Proceedings pp. 11-15, Brussels: SAGB.

Bartel, A.P. and Thomas, L.G. (1987) Predation through regulation: the wage and profit impacts of OSHA and EPA, Journal of Law \& Economics 30, 239-64.

Bergen Declaration (1990) Bergen ministerial declaration on sustainable development in the ECE Region, UN Doc. A/CONF.151/PC/10, Yearbook of International Environmental Law 1, 429-40.

Bignami, F.E. (1999) The democratic deficit in European Community rulemaking: a call for notice and comment in comitology. Harvard International Law Journal 40, 451-515.

Bilefsky, D. (2000) National news: French Reject blood ban, News Digest, Financial Times (London), 24 February available in Lexis Nexis Academic Universe.

Blakeslee, S. (2001) A marker for mad cow disease may be found in urine, NY Times, 17 July, D5.

Blanchfield, M. (2000) Canada widens blood ban: mad cow precaution bars donors who spent six months in France, Ottawa Citizen (Ottawa, Ont.) 1 September, available in Global NewsBank.

Bodansky, D. (1991) Scientific uncertainty and the precautionary principle, Environment 33, 4-5, 43-44.

Bodansky, D. (1993). The United Nations framework convention on climate change: a commentary, Yale Journal of International Law 18, 451-504.

Boehmer-Christiansen S. (1994) The precautionary principle in Germany - enabling government, in T. O'Riordan and J. Cameron (eds) Interpreting the Precautionary Principle, London: Cameron May, pp. 31-60.

Bostock, C. (2000) vCJD could be transmitted through blood transfusions, The Lancet 356, 955-99.

Breyer, S.G. (1993) Breaking the Vicious Circle, Cambridge: Harvard University Press. 
Brickman, R., Jasanoff, S. and Ilgen, T. (1986) Controlling Chemicals: The Politics of Regulation in Europe and the United States, Ithaca and London: Cornell University Press.

Cadot, O. and Vogel, D. (2001) France, the United States, and the biotechnology dispute, Brookings Foreign Policy Studies, January. Available at $<\mathrm{http} / /$ www.brookings.edu/fp/cusf/ analysis/biotech.htm>.

Cameron, J. and Abouchar, J. (1991) The precautionary principle: a fundamental principle of law and policy for the protection of the global environment, Boston College International \& Comparative Law Review 14, 1-27.

Charnovitz, S. (2000) The supervision of health and biosafety regulation by world trade rules, Tulane Environmental Law Journal 13, 271-302.

Clinton, W.J. (1993) Executive Order 12866: Regulatory Review, 30 September, Federal Register $58,51735$.

Comer, P.H. (1998) Assessing the risk of exposure to BSE from beef on the bone. Society for Risk Analysis - Europe, Annual Conference Proceedings, 'Risk Analysis: Opening the Process,' 11-14 October, Paris, pp. 605-14.

Commission of the European Communities (CEC) v. French Republic (2001) European Court of Justice, Case C-1/00 (Failure of a Member State to fulfil its obligations - Refusal to end the ban on British beef and veal), decided 13 December, European Court Reports 2001, p. I-09989.

Cross, F.B. (1996) Paradoxical perils of the precautionary principle, Wash. \& Lee Law Review 53, 851-925.

Daalder, I. (2001) Are the United States and Europe heading for divorce? International Affairs 77(3), 531-45.

Daley, S. (2000a) More and more, Europeans find fault with US: wide range of events viewed as menacing, $N Y$ Times, 9 April, p.A1.

Daley, S. (2000b) As mad cow disease spreads in Europe, consumers panic, NY Times, 1 December, p.A1.

Daley, S. (2000c) Europe takes toughest steps to fight mad cow disease, NY Times, 5 December, p.A3.

Daley, S. (2001) French report faults response to mad cow crisis, NY Times, 18 May, p.A10.

Emiliou, N. (1996) The Principle of Proportionality in European Law, London \& Cambridge MA: Kluwer Law International.

Ethyl Corp. v. EPA (1976). 541 F.2d 1 (DC Cir.).

European Commission (1996) Decision of 27 March 1996 on emergency measures to protect against bovine spongiform encephalopathy, Official Journal of the European Communities, JOL 1996/78-18EN, pp. 47-48.

European Commission (1998) Decision 98/692/EEC of 25 November 1998, Official Journal of the European Communities, JOL 1998/328EN, pp. 28-35.

European Commission (1999a) Opinion of the Scientific Steering Committee, on the Scientific Grounds of the Advice of 30 September 1999 of the French Food Safety Agency (the Agence Française de Sécurité Sanitaire des Aliments, AFSSA), to the French Government on the Draft Decree amending the Decree of 28 October 1998 establishing specific measures applicable to certain products of bovine origin exported from the United Kingdom. Adopted at its meeting of 28-29 October 1999 (edited following a written procedure $(30.10-15.11 .99)$ and re-edited at the SSC meeting of 9-10 December 1999), European Commission, Director General for Health and Consumer Protection.

European Commission (1999b) Seventeenth Annual Report on the Monitoring of Community Law (1999), COM/2000/0092, Case Number C-1/2000.

European Commission (2000) Communication from the Commission on the Precautionary Principle, COM(2000)1, Brussels, 2 February 2000 (available at $<$ http://europa.eu.int/comm/ dgs/health_consumer/library/pub/pub07_en.pdf $>$ ). 
European Council (1981) Directive 81/602/EEC of 31 July 1981 concerning the prohibition of certain substances having a hormonal action and of any substances having a thyrostatic action (and subsequent amendments), JOL $222,07 / 08 / 1981$ pp. 32, 33

European Council (1990) Decision of 25 April 1990 concerning the administration of bovine somatotrophin, 90/218/EEC, JOL 1990/116, p. 27 (and subsequent amendments).

European Council (1999) Decision of 17 December 1999 concerning the placing on the market and administration of bovine somatotrophin (and repealing Decision 90/218/EEC), 99/879/EEC, JOL 1999/331, p. 71.

European Environment Agency (EEA) (2001) Late Lessons from Early Warnings: The Precautionary Principle 1896-2000, Environmental Issue Report No. 22 (Luxembourg: Office for Official Publications of the European Communities).

European Union (1997) Treaty of Amsterdam amending the treaty on European Union, the treaties establishing the European Communities and certain related acts, Oct. 2, 1997, (Article 174, formerly Article 130r), Official Journal (C 340) 1 (consolidated and renumbered Nov. 10, 1997, OJ (C 340) 3), 254-55. Reprinted as, European Union: consolidated version of the treaty on European Union and consolidated version of the treaty establishing the European Community, International Legal Materials, 37, 56-142 (Article 174 [ex 130r] appears at 116-7).

Faull, J. (2000) EU Ban on US Beef Based on Firm Evidence, Letter, The Financial Times, 6 July.

Funtowicz, S.O. and Ravetz, J.R. (1990) Uncertainty and Quality in Science for Policy, Dordrecht, The Netherlands; Narwell, MA: Kluwer Academic Publishers.

Geistfeld, M. (2001) Reconciling cost-benefit analysis with the principle that safety matters more than money, NYU Law Review 76, 114-189.

Glennon, M. and Stewart, A. (1998) The United States: taking environmental treaties seriously, in E.B. Weiss and H. Jacobson (eds) Engaging Countries, Cambridge, MA: MIT Press.

Goethals, C., Ratzan, S.C. and Demko, V. (1998) The politics of BSE: negotiating the public's health, in S.C. Ratzan (ed.) The Mad Cow Crisis - Health and the Public Good, London: UCL Press.

Graham, J.D. and Wiener, J.B. (eds) (1995) Risk vs. Risk: Tradeoffs in Protecting Health and the Environment, Cambridge: Harvard Univ. Press.

Henningsen, J. (1992) The seven principles of european environmental policies, in Toward a Transatlantic Environmental Policy, Washington DC: The European Institute.

Hernandez, R. (2001) Citing mad cow, FDA panel backs blood donor curbs, NY Times, 29 June, p.A23.

Hey, E. (1992) The precautionary concept in environmental policy and law: institutionalizing caution, Georgetown International Environmental Law Review 4, 303-18.

Hill, A.F. Joiner, S., Linehan, J., Desbruslais, M., Lantos, P.L. and Collinge, J. (2000) Speciesbarrier-independent prion replication in apparently resistant species, Proceedings of the National Academy of Sciences 97, 10248-53.

Horowitz, D.L. (2000) Ethnic Groups in Conflict (2nd edn), Berkeley: University of California Press.

Industrial Union Dept., AFL-CIO v. American Petroleum Institute (1980) (the 'Benzene' case). 448 US 607.

Irwin, A. (1997) Risk-assessment system relies too much on science, The Daily Telegraph (UK), 4 December.

Jackson, V. (1999) Ambivalent resistance and comparative constitutionalism: opening up the conversation on 'proportionality,' rights and federalism, University of Pennsylvania Journal of Constitutional Law 1, 583-639.

Jasanoff, S. (1986) Risk Management and Political Culture, New York: Russell Sage Foundation. Jasanoff, S. (1998) Contingent knowledge: implications for implementation and compliance, in E.B. Weiss and H. Jacobson (eds) Engaging Countries: Strengthening Compliance with International Environmental Accords, Cambridge MA: MIT Press, p. 63. 
Kagan, R.A. (2001) Adversarial Legalism: The American Way of Law, Cambridge, MA : Harvard University Press.

Karpowicz-Lazreg, C. and Mullet, E. (1993) Societal risk as seen by the French public, Risk Analysis 13(3), 253-8.

Kempton, W. and Craig, P.P. (1993) European perspectives on global climate change, Environment Magazine, April, 16-20, 41-45.

Knight, F. (1933) Risk, Uncertainty, and Profit, Boston, New York: Houghton Mifflin Co.

Leake, J. (2000) Blood donors feared to have spread CJD, The Sunday Times (UK), 17 September.

Levy, D.L. and Newell, P. (2000) Oceans apart? Environment Magazine, November 9.

Litfin, K.T. (1994) Ozone Discourses, New York: Columbia University Press.

Lofstedt, R. and Vogel, D. (2001) The changing character of consumer and environmental regulation: a comparison of Europe and the United States, Risk Analysis 21, 399-405.

Lyall, S. (2000) British wrongly lulled people on 'mad cow', report finds, NY Times, 27 October, A8.

Lynch, D. and Vogel, D. (2000) Apples and oranges: comparing the regulation of genetically modified food in Europe and the United States. Paper prepared for the American Political Science Association annual meeting, 31 August - 3 September.

McNeil, D. Jr. (2000) Protests on new genes and seeds grow more passionate in Europe, $N Y$ Times, 14 March, A1, A10.

Minder, R. (2000) France bans beef on bone and suspect feed, Financial Times, 15 November.

Nye, J.S., Jr., Zelikow, P.D. and King, D.C. (eds) (1987) Why People Don't Trust Government. Cambridge, MA: Harvard University Press.

Page, T. (1978) A generic view of toxic chemicals and similar risks, Ecology Law Quarterly 7, 207-44.

Prusiner, S. (1997) Prion diseases and the BSE crisis, Science 278, 245-51.

Raffensperger, C. and Tickner, J. (eds) (1999) Protecting Public Health and the Environment: Implementing the Precautionary Principle, Washington DC: Island Press.

Reaney, P. (1998a) Focus - Britain to purify blood to remove CJD risk, Reuters, 17 July, available in Global NewsBank.

Reaney, P. (1998b) UK to import blood plasma as 'mad cow' move, Reuters, 26 February, available in Global NewsBank.

Redwood, J. (2001) Stars and Strife: The Coming Conflicts Between the USA and the European Union, Basingstoke, Hampshire and New York: Palgrave.

Renn, O. and Rohrmann, B. (eds) (2000) Cross-Cultural Risk Perception: A Survey of Empirical Studies, Dordrecht: Kluwer Academic Publishers.

Rhodes, R. (1997) Deadly Feasts, New York: Simon \& Schuster.

Richter, S.-G. (2000) The US consumer's friend, NY Times, 21 September, A31.

Robinson, N.A. (1997) Introduction, in N.A. Robinson (ed.) Comparative Environmental Law and Regulation v, xiii, Dubbs Ferry, NY: Oceana Publications.

Rogers, M. (2001) Scientific and technological uncertainty, the precautionary principle, scenarios and risk management, Journal of Risk Research 4(1), 1-15.

Rose-Ackerman, S. (1985) Controlling Environmental Policy: The Limits of Public Law in Germany and the United States, New Haven: Yale University Press.

Rumbelow, H. (2000) CJD victim may have infected her unborn baby, The Times (UK), 18 September.

Sand, P.H. (2000) The precautionary principle: a european perspective, Human and Ecological Risk Assessment 6, 445-58.

Sandin, P. (1999) Dimensions of the precautionary principle, Human and Ecological Risk Assessment 5, 889-908.

Sands, P. (1995) Principles of International Environmental Law, New York: Manchester University Press.

Schroeder, C. (1998) Rational choice versus republican moment explanations for environmental laws, 1969-73, Duke Environmental Law \& Policy Forum 9, 29-60. 
Shrader-Frechette, K. (1991) Risk and Rationality: Philosophical Foundations for Populist Reforms, Berkeley: University of California Press.

Slaughter, A.M. (2000) Governing the global economy through government networks, in M. Byers (ed.) The Role of Law in International Politics, Oxford and New York: Oxford University Press, pp. 177-205.

Slovic, P. (1987) Perceptions of risk, Science 236, 280-5.

Slovic, P., Flynn, J. and Layman, M. (1991) Perceived risk, trust, and the politics of nuclear waste, Science 254, 1603-7.

Slovic, P., Flynn, J., Mertz, C.K., Poumadere, M. and Mays, C. (2000) Nuclear power and the public: a comparative study of risk perception in France and the United States, in O. Renn and O. Rohrmann Cross-Cultural Risk Perception: A Survey of Empirical Studies pp. 55-102, Dordrecht: Kluwer Academic Press.

Stecklow, S. (1999) 'Mad Cow' fears lead to blood ban in US, The Wall Street Journal 18 August, B6. Stewart, R.B. (2002) Environmental regulatory decisionmaking under uncertainty, Research in Law and Economics 10, 71-152.

Stone, C.D. (2000) Is there a precautionary principle? Paper based on remarks presented at the United Nations University, Tokyo, 18 March, and at the United Nations Headquarters, 22 September.

Sunstein, C.R. and Kuran, T. (1999) Availability cascades and risk regulation, Stanford Law Review 51, 683-768.

Tagliabue, J. (2001) US plan to halt blood imports worries Europe, NY Times 17 July, A1.

Tajfel, H. (1970) Experiments in intergroup discrimination, Scientific American 223 (November), 96-102.

Toronto Sun (1999) Blood ban fears denied. 16 July, 21.

TVA v. Hill (1978) 437 US 153.

UK (2000) Findings and conclusions (volume 1), in Phillips of Worth Matravers, Bridgeman, J. and Ferguson-Smith, M., The BSE Enquiry Report ('The Phillips Report', in 16 volumes), 26 October, London: HM Stationary Office (available at http://www.bse.org.uk/index.htm).

UK v. CEC (1998) European Court of Justice, Case C-180/96, judgement dated 5 May, European Court Reports 1998, p. I-02265.

USDA (1991) Animal and plant health inspection service, bovine spongiform encephalopathy, Federal Register 56, 63865-70.

USDA (2000) Animal and Plant Health Inspection Service, Bovine Spongiform Encephalopathy (visited on September 27, 2000) < http://www.aphis.usda.gov/oa/bse/>.

US FDA (1989) FDA Reviewing BST for Cows, August 4 (viewed on September 26, 2000), $<$ http://www.fda.gov/bbs/topics/ANSWERS/ANS00140.html $>$.

US FDA (1997) Bovine Spongiform Encephalopathy and Creutzfeldt-Jakob Disease Fact Sheet, January 2, 1997 (visited September 26, 2000) < http://www.fda.gov/cvm/fda/infores/updates/ bse/bsefact.html>.

US FDA (1998) Center for Veterinary Medicine. CVM Update, FDA Guidance on BSE Feed Regulation Available, July 14, 1998, (viewed on September 27, 2000), < http://www.fda.gov/ cvm/fda/infores/updates/bse76up.htm >.

US FDA (1999a) Report on the FDA's Review of the Safety of Recombinant Bovine Somatotropin, February 10, (viewed on September 26, 2000) $<$ http://www.fda.gov/cvm/fda/ infores/other/rbrptfnLawhtm>.

US FDA (1999b) Center for Veterinary Medicine, FDA Analysis of DGXXIV Report on Public Health Aspects of BST (updated April 15, 1999) < http://www.fda.gov/cvm/fda/infores/updates/ dg24up.htm>.

US FDA (1999c) Guidance for industry: revised precautionary measures to reduce the possible risk of transmission of Creutzfeldt-Jakob disease (CJD) and new variant Creutzfeldt-Jakob Disease (vCJD) by blood and blood products, Federal Register 64, 44739 (August 17). 
US FDA (1999d) Advisory Committee on Transmissible Spongiform Encephalopathies, Hearings of 2 June 1999, SAG Corp. Transcript, p.46 (Statement of Dr. Williams) (downloaded from $<$ http://www.fda.gov/cber> under Minutes of 1999 Conferences/Meetings).

USTR (1996) Office of the US Trade Representative, Press Release: Statement of Mickey Kantor, January 11 (viewed on September 27, 2000), < http://www.ustr.gov/releases/1996/01/96-03.html>

USTR (1999) Office of the US Trade Representative Fact Sheet, US Response to EU Beef Import Ban, July (viewed on September 27, 2000), < http://www.ustr.gov/releases/1999/07/fact. pdf>

Vogel, D. (1985) National Styles of Regulation: Environmental Policy in Great Britain and the United States, Ithaca and London: Cornell University Press.

Vogel, D. (1995) Trading Up: Consumer and Environmental Regulation in a Global Economy, Cambridge: Harvard University Press.

Vogel, D. (1997) Barriers or Benefits: Regulation in Transatlantic Trade, Washington DC: Brookings Institution Press.

Vogel, D. (2001a) Risk regulation in contemporary Europe: an American perspective. Presentation at the Center for Analysis of Risk and Regulation, London School of Economics, 29 January.

Vogel, D. (2001b) Ships passing in the night: the changing politics of risk regulation in Europe and the United States. Robert Schuman Centre for Advanced Studies, European University Institute, Working Paper 2001/16.

Wagner, W.E. (1995) The science charade in toxic regulation, Columbia Law Review 95, 1613-723.

Watson, A. (1993) Legal Transplants: An Approach to Comparative Law, 2nd edn, Athens: University of Georgia Press.

Weber, E.U. and Hsee, C.K. (2000) Culture and individual judgment and decisionmaking, Applied Psychology: an international review 49(1), 32-61.

Wiener, J.B. (1995) Law and the new ecology: evolution, categories and consequences, Ecology Law Quarterly 22, 325-57.

Wiener, J.B. (1998) Managing the iatrogenic risks of risk management, Risk: Environment Health \& Safety 9, 39-84.

Wiener, J.B. (1999) On the political economy of global environmental regulation, Georgetown Law Journal 87, 749-75.

Wiener, J.B. and Rogers, M.D. (forthcoming) The Reality of Precaution, at <http://www.env. duke.edu/solutions/precaution_project.html>.

World Trade Organization (1997) WTO Panel Report, EC Measures Concerning Meat and Meat Products (Hormones) - Complaint by the United States, WT/DS26/R/USA (18 August 1997), available at $<$ http://www.wto.org/dispute/distab.htm $>$.

World Trade Organization (1998) WTO Appellate Body Report, EC Measures Concerning Meat and Meat Products (Hormones), AB-1997-4, WT/DS26/AB/R, WT/DS48/AB/R (16 January 1998), available at < http://www.wto.org/dispute/distab.htm>. 